\title{
Physicochemical Characteristics of Saudi Arabian Locally Produced Raw and Diluted Honeys and Their Relations to Antimicrobial Activity
}

\author{
M.S. El-Shahawi ${ }^{1 \dagger}$ and R. Al-Hindi ${ }^{2}$ \\ ${ }^{1}$ Department of Chemistry, Faculty of Science, King Abdulaziz University, P.O. Box 80203, Jeddah 21589, \\ Saudi Arabia, \\ 2. Biology Department, Faculty of Science, King Abdulaziz University, Jeddah, Saudi Arabia,
}

\begin{abstract}
The physicochemical characteristics and antibacterial activity of Saudi Arabia honeys were studied for the first time. The levels of free and total acidity, $\mathrm{pH}$, ash and moisture content were in the range $1.6 \pm 0.17-15.1 \pm 0.1 \mathrm{meg} / \mathrm{kg}, 2.77 \pm 0.06$ $5.37 \pm 0.04,1.1 \pm 0.02-1.7 \pm 0.03 \%$ and $<18.0 \%$, respectively. Lovibond comparator color scale $(P$, mm) of samples was ranged from water white $(P=0.0-1.3)$, extra light Amber $(P=38.14-46.57)$, light Amber $(P=60.39-75.54)$, Amber $(P=86.72-$ 110.08), dark $(P=142.39-348.44)$ and very dark shade $(P=541.84)$. Dark honeys showed excellent inhibitory effects against bacterial growth. Excellent correlation between color of raw and diluted $(>10.0 \% \mathrm{~m} / \mathrm{v})$ honey and antimicrobial activity was noticed. Honey species from different floral sources posses' strong antioxidant and anti bacterial activities and are scavengers of active oxygen species.
\end{abstract}

\section{Indexing terms/Keywords}

Physicochemical characterization; Antibacterial activity; Total acidity; Lovibond comparator scale; Saudi Arabia honeys.

${ }^{\dagger}$ Corresponding author: Email address: malsaeed@kau.edu.sa; mohammad_el_shahawi@yahoo.co.uk On sabbatical leave from Department of Chemistry, Faculty of Science, Damiatta University, Damiatta, Egypt

\section{Council for Innovative Research}

Peer Review Research Publishing System

Journal: Journal of Advances in Chemistry

Vol. 10, No. 6

editorjaconline@gmail.com

www.cirjac.com 


\section{INTRODUCTION}

Honey is the natural substance produced by honey bees, Apis mellifera, in almost every country of the world and it has been used since the earliest time [1]. (Blasa et al., 2006). It is widely appreciated as the only concentrated form of sugar available worldwide and is also used as a food preservative [2].The antibacterial property of honey has long been recognized in vivo and in vitro as reported by Aljadi \& Yusoff, 2003 [3]. The biological activities (antimicrobial and antibacterial properties) of the honey have been attributed largely to $\mathrm{H}_{2} \mathrm{O}_{2}$ and non-peroxide compounds of the samples [4]. The non-peroxide anti -bacterial activity of the honey has been associated with sugar concentration, antioxidant and proteinaceous compounds present in honey [3, 5-7].

Natural honey had enhanced the function of liver in treated animals with Doxorubicin (DOX) + honey and reduced the pathological effects of DOX on the morphological symptoms as well in the hepatocytes [8]. Honey also can act as a natural antioxidant which is important with the recent emphasis on decreasing the use of artificial preservation in food and perception of honey as a healthy sweetener [9].Total phenolic content/antioxidant levels in honey including quercetin, catechin, gallic acid, caffeic acid and ferulic acid have been estimated by Al Lawati et al., 2014 [10]. The effect of formaldehyde and other enhancers on CL signal intensity was extensively investigated. The method was applied to honey samples. In this study, nine different honey samples have exhibited total phenolic/antioxidant levels of 41.2 to $765.4 \mathrm{mg}$ $\mathrm{kg}^{-1}$ with respect to gallic acid. The Folin-Ciocalteu (FC) assay results were well correlated with the chemiluminescence results.

Color and transparency of honey have been correlated with pigment content, antioxidant properties and suspended particles e.g. pollen [11]. The acidity of honey $(\mathrm{pH} 3.2-4.5)$ has been attributed to organic acids resulting from enzymatic action in the ripening nectar $[6,12]$. Water content $(<18 \mathrm{w} / \mathrm{w} \%)$ of the honey has been correlated to weather, nectar conditions, humidity inside the hive and treatment of honey during its extraction and production, storage steps and other environmental factors [12].

The functional properties of honey species in foreign countries are well studied. However, the physicochemical properties of Saudi Arabia honey are not fully investigated. To the best of our knowledge, no study on the relationship between physicochemical properties and antibacterial activity of raw and diluted Saudi Arabian honeys was performed. Thus, in thethis study, the physicochemical properties (color, free and total acidity, $\mathrm{pH}$, ash and moisture content) of raw and diluted honey species were evaluated. Honey species from different floral sources posses' strong antioxidant and ant bacterial activities and are scavengers of active oxygen species. Therefore, our results obtained are expected to be used as a reference for food composition and nutritional value of this mushroom.

\section{EXPERIMENTAL}

\subsection{Apparatus and reagents}

A Perkin - Elmer Lambda 25 (Shelton, CT, USA) spectrophotometer (190 - $1100 \mathrm{~nm}$ ) and a Corporation Precision Scientific mechanical shaker (Chicago, USA) with a shaking rate of $10-250 \mathrm{rpm}$ were used. A Milli-Q Plus de ionized water system and an Orion pH meter model 720 (MA, USA), an incubator (Imperial III), oven (Daihan Lab-Tech Co.), autoclave, UV cabinet (Esco, Germany), centrifuge (Clay Adams) and water bath (Techne, England) were used. The brand of twenty natural honey samples and their commercial names were collected from Saudi Arabia beekeepers during the period 2007-2008 and stored in dark at $4{ }^{\circ} \mathrm{C}$ (Table 1). The Staphylococcus aureus ATCC 24213, Micrococcus luteus ATCC 49732 and Escherichia coli ATCC 25922 microorganisms were delivered were from the Microbiology laboratory, King Abdulaziz University hospital [13]. 
Table 1 Description of Saudi Arabian locally produced honey samples (personal name) collected from different regions

\begin{tabular}{|c|c|c|c|}
\hline $\begin{array}{l}\text { Sample } \\
\text { No. }\end{array}$ & Trade name & Floral origin & Collection region \\
\hline 1 & Rabea Alfayyadh & Multifloral & $\begin{array}{c}\text { Al-qaseem } \\
\text { (North of Kingdom) }\end{array}$ \\
\hline 2 & Wadi Reeth & Unifloral (Sidr) & $\begin{array}{l}\text { Gizan-Wadi Reeth } \\
\text { (South of Kingdom) }\end{array}$ \\
\hline 3 & Takhfa & Multifloral & $\begin{array}{c}\text { Al-qaseem } \\
\text { (North of Kingdom) }\end{array}$ \\
\hline 4 & Alfagara & Multifloral & $\begin{array}{l}\text { Al-Madinah Al-munawrah-Alfagara } \\
\text { (North of Kingdom) }\end{array}$ \\
\hline 5 & Albojaidi & Unifloral (Gatad) & $\begin{array}{l}\text { Makkah Al-Mukarramah-Wadi Albojaidi } \\
\text { (West of Kingdom) }\end{array}$ \\
\hline 6 & Sidr Om Alasafeer & Unifloral (Sidr) & $\begin{array}{l}\text { Makkah Al-Mukarramah } \\
\text { (West of Kingdom) }\end{array}$ \\
\hline 7 & Alnadheem & Multifloral & N.A. \\
\hline 8 & Alhandhal & Unifloral (Handhal) & N.A. \\
\hline 9 & Taba & Unifloral (Talh) & $\begin{array}{l}\text { South east of Hail } \\
\text { (North of Kingdom) }\end{array}$ \\
\hline 10 & Alkorrath & Unifloral (Korrath) & South of kingdom \\
\hline 11 & Rabea Algobbah & Multifloral & $\begin{array}{l}\text { Al-qaseem, Al Gobbah } \\
\text { (North of Kingdom) }\end{array}$ \\
\hline 12 & Alsail Alkabeer & Unifloral (Somrah) & $\begin{array}{c}\text { Alsail Alkabir } \\
\text { (West of Kingdom) }\end{array}$ \\
\hline 13 & Almeshaan & Multifloral & $\begin{array}{c}\text { Hail } \\
\text { (North of Kingdom) }\end{array}$ \\
\hline 14 & Altenhat & Multifloral & $\begin{array}{l}\text { North east of Riyadh } \\
\text { (North of Kingdom) }\end{array}$ \\
\hline 15 & Jabal Algahr & Multifloral & $\begin{array}{c}\text { Gizan } \\
\text { (South of Kingdom) }\end{array}$ \\
\hline 16 & Aba Alwrood & Multifloral & $\begin{array}{l}\text { Al-qaseem Aba-Alwrood } \\
\text { (North of Kingdom) }\end{array}$ \\
\hline 17 & Wadi Daraa & Multifloral & $\begin{array}{c}\text { Makkah Al-Mukarramah- Dehban } \\
\text { (West of Kingdom) }\end{array}$ \\
\hline 18 & Rabea Alsahra & Multifloral & Nufud desert \\
\hline 19 & Motreba & Multifloral & North of Lina \\
\hline 20 & Bani Kabeer & Multifloral & $\begin{array}{c}\text { Al baha } \\
\text { (South of Kingdom) }\end{array}$ \\
\hline
\end{tabular}




\subsection{Measurement of antibacterial activity}

Antibacterial activity of honey samples was determined following the method reported by Patton et al., 2006 [14] as follows: i. suspensions of bacterial isolates of $S$. aureus, M. luteus and $E$. coli were prepared by the reported turbidity standard McFarland 0.5 procedures [15] ; ii An accurate volume $(100 \mu \mathrm{L})$ of the suspension was inculpated onto Muller Hinton agar by streaking plate method; iii six wells were made on the inoculated agar using sterile cork borer (diameter $6 \mathrm{~mm})$, iv a $90 \mu \mathrm{L}$ of honey sample solutions $(10-100 \% \mathrm{~m} / \mathrm{m})$ was taken and transferred to the designated wells on the agar plates and inoculated plates and incubated at $37^{\circ} \mathrm{C}$ for $24 \mathrm{~h}$. The average $(\mathrm{n}=3)$ of inhibition zone's diameter (mm) was measured and the inhibition zone swabs were finally cultured on a nutrient agar and incubated for $24 \mathrm{~h}$ at $37^{\circ} \mathrm{C}$.

\subsection{Measurements of total acidity, ash- and moisture content, $\mathrm{pH}$ and color}

The acidity, ash and moisture contents, $\mathrm{pH}$ and color of the test honey samples were determined as reported [16, 17] as follows:

i. Acidity measurement: An accurate weight (5- $10 \pm 0.06 \mathrm{~g})$ of the homogenizedhoneys samples in deionized water (50$75 \mathrm{~mL}$ ) was titrated with standard carbonate-free $\mathrm{NaOH}(0.1 \mathrm{~N})$ until the $\mathrm{pH}$ reached 8.5. The amount of consumed $\mathrm{NaOH}$ is equivalent to the acidity value.

ii. Ash content $(\% \mathrm{w} / \mathrm{w})$ was determined by weighing an accurate weight $(5-10 \pm 0.06 \mathrm{~g})$ of the honey sample was placed in a porcelain crucible in a muffle furnace for $6 \mathrm{~h}$ at $550^{\circ} \mathrm{C}$. The ash content was then computed from the difference of gram crucible weight before and after ignition.

iii. Moisture (\%): Moisture content was determined by weighing an accurate weight $(5-10 \pm 0.06 \mathrm{~g})$ of honey sample in a porcelain crucible. The sample was then placed in an oven at $120^{\circ} \mathrm{C}$ for $4 \mathrm{~h}$. The moisture content $(\% \mathrm{~m} / \mathrm{m})$ finally calculated from the difference in weight before and after drying.

iv. $\mathrm{pH}$ measurements: $\mathrm{pH}$ was determined by placing an accurate weight $(5-10 \pm 0.06 \mathrm{~g})$ of the homogenized honey in deionized water $(50.0 \mathrm{~mL})$ and read the $\mathrm{pH}$ directly by $\mathrm{pH}$ meter.

v. Color measurements: Color of samples was determined by heating the honey samples to $50^{\circ} \mathrm{C}$ to dissolve sugar crystals and subsequent dilution with deionized water to $50 \%(\mathrm{w} / \mathrm{v})$. The absorbance (Abs) of honey samples were measured at $635 \mathrm{~nm}$ and based on $\mathrm{P}$ fund scale $(\mathrm{mm})$, color of the honey samples was determined using the equation (Patton et al., 2006):

$P$ fund $=-38.70+371.39 \times$ Abs

where $P=$ Lovibond comparator color scale.

\subsection{Statistical treatment of data}

Data were expressed as means \pm standard deviations (SD) of three measurements and analyzed by SPSS V.13 (SPSS Inc., Chicago, USA). One way analysis of variance (ANOVA) and the Duncan's New Multiple-range tests were successfully used at $P<0.05$.

\section{RESULTS AND DISCUSSION}

Phenols are important constituent of honey because of their scavenging ability by the available hydroxyl group [18]. Honey constituents also play an important role in stabilizing lipid oxidation [19].The high levels of phenolic compounds in honey extract reflect the radical scavenging activity.

\subsection{Influence of physicochemical characteristics of raw honey on antibacterial activity}

The total acidity varied between $2.0 \pm 0.17$ (sample 10) and $13.1 \pm 0.46 \mathrm{meq} / \mathrm{kg}$ (sample 20). The average value (7.55 $\pm 0.32 \mathrm{meq} / \mathrm{kg}$ ) was found lower than the data of Finola et al. $2007(20.65 \pm 0.12 \mathrm{meq} / \mathrm{kg})$. At $P=0.01$, significant correlation coefficients $\left(R^{2}\right)$ between the total acidity and the inhibition zone $(\mathrm{mm})$ for $S$. aureus $\left(R^{2}=0.93\right)$, M. luteus $\left(R^{2}=0.62\right)$ and E. coli $\left(\mathrm{R}^{2}=0.74\right)$ were noticed (Fig. $\left.1 \mathrm{~A}\right)$.

The ash content (\%) of the samples was varied between $1.1 \pm 0.02-1.7 \pm 0.03 \%$ in agreement with Finola et al. 2007 (0.02- $0.18 \mathrm{~g} \%$ ) [16] and Al-Doghairi, et al. 2007 (0.001-10.11\%) [20].The ash content is mainly dependent on the soil type and the nectar bearing plant [18]. At $P=0.01$ significant, the ash content was poorly correlated with the inhibition zone $(\mathrm{mm})\left(\mathrm{R}^{2}=0.41,0.50\right.$ and 0.37$)$ for $S$. aureus, M. luteus and $E$. coli, respectively (Fig. $\left.1 \mathrm{~B}\right)$. 

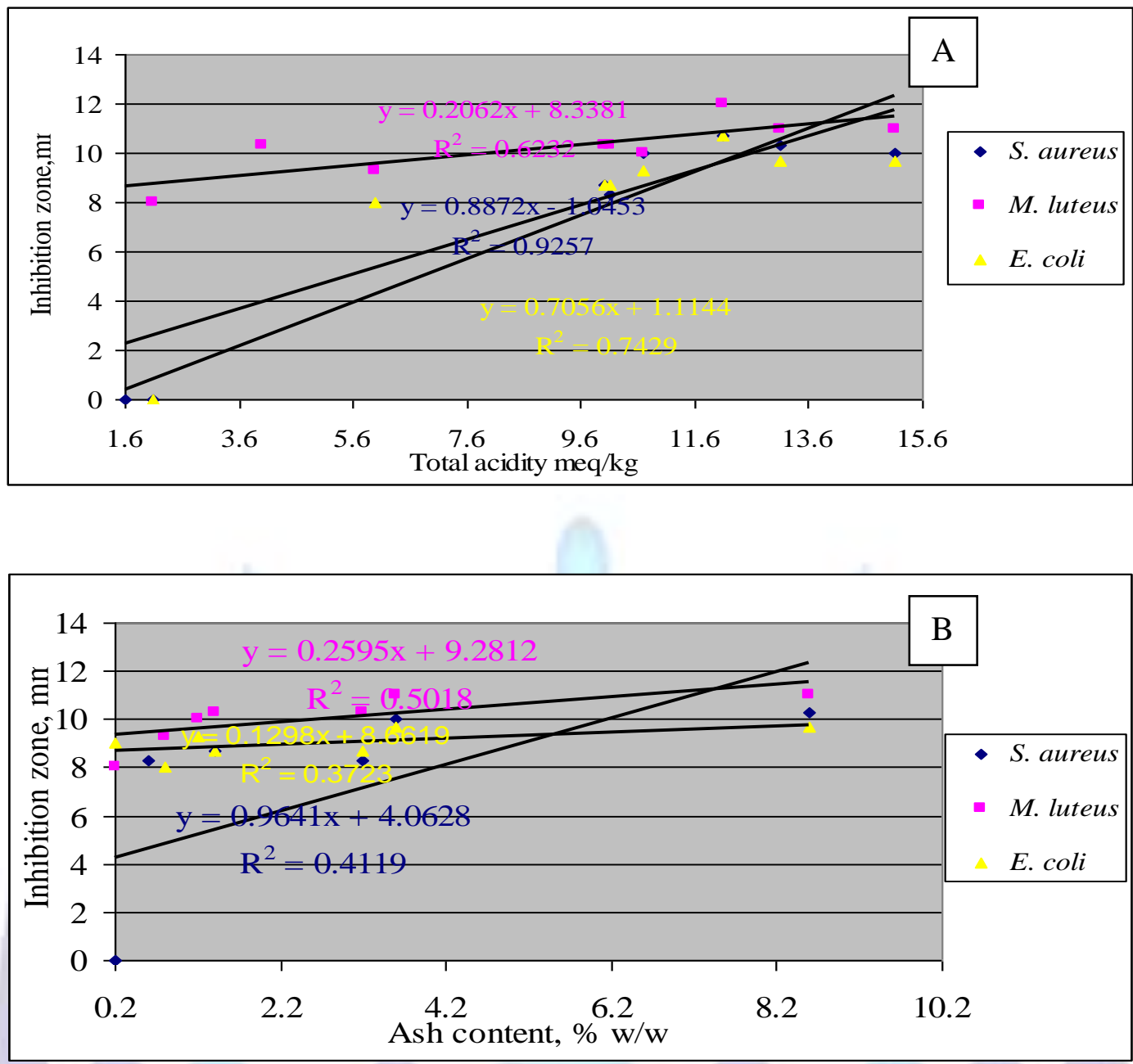

Fig.1. Plot of total acidity $(\mathrm{meq} / \mathrm{kg})(\mathrm{A})$ and ash content $(\% \mathrm{w} / \mathrm{w})(\mathrm{B})$ of honey samples $v \mathrm{~s}$. inhibition zone $(\mathrm{mm})$ of $\mathrm{S}$. aureus, $M$. luteus and $E$. coli.

Moisture content (\%) of the honey samples was in the range $6.6 \pm 0.12-17.6 \pm 0.05 \%$. The average value $(12.1 \pm 0.085 \%)$ was lower than the average value reported (14.9\%) [20] and Anupama et al., 2003 (19.8\%w/w) [21]. The fermentation process is extremely low and guarantees the very long shelf- life of honey, without fermentation risk. The value of the moisture content is known to depend on the osmotic yeasts [22] and it is also responsible for the fermentation that occurred naturally in the honey. The moisture content was poorly correlated with the inhibition zone ( $\mathrm{mm}$ ) of $S$. aureus $M$. luteus and $E$. coli, respectively (Fig. $2 \mathrm{~A}, \mathrm{R}^{2}=0.73$ ).

The $\mathrm{pH}$ of honey samples varied from $2.77 \pm 0.06$ to $5.33 \pm 0.09$ in good agreement with the data reported (3.51-5.27) [18, 20]. Organic acids e.g. Gluconic acid and inorganic ions are most likely responsible for acidity (Kucuk et al., 2007) of honey [6]. Samples of $\mathrm{pH}>5$ are characterized by low purity and quality [6]. The $\mathrm{pH}$ values of the honey samples were inversely proportional with the inhibition zone, $\mathrm{mm}\left(\mathrm{R}^{2}=0.73,0.67\right.$ and 0.15$)$ for the organisms of $S$. aureus $M$. luteus and E. coli, respectively (Fig. 2 B). The inhibition zones are comparable to $\mathrm{pH}$ values of the honeys from U.S. ( $\mathrm{pH}$ range 3.4$6.1)$.

\subsection{Influence of physicochemical properties of diluted honey on antibacterial activity}

The inhibition of various diluted $(10-100 \% \mathrm{w} / \mathrm{w})$ twenty honey samples vs. S. aureus, M. luteus and $E$. coli was investigated. The results are demonstrated in Table 2 . Diluted honey content $\leq 10 \%$ showed no significant effect, while diluted samples at concentrations $>10 \%$ on nutrient agar medium showed grow in inhibition zones on increasing honey content. All samples showed bacterio -static effect against organisms. Some few samples at $80 \%$ and $100 \%$ (w/w) revealed bactericidal and clear antibacterial effects. The average diameters of inhibition zones ( $\mathrm{mm}$ ) of $S$. aureus, $M$. luteus and E. coli by raw honey samples were 33.9 

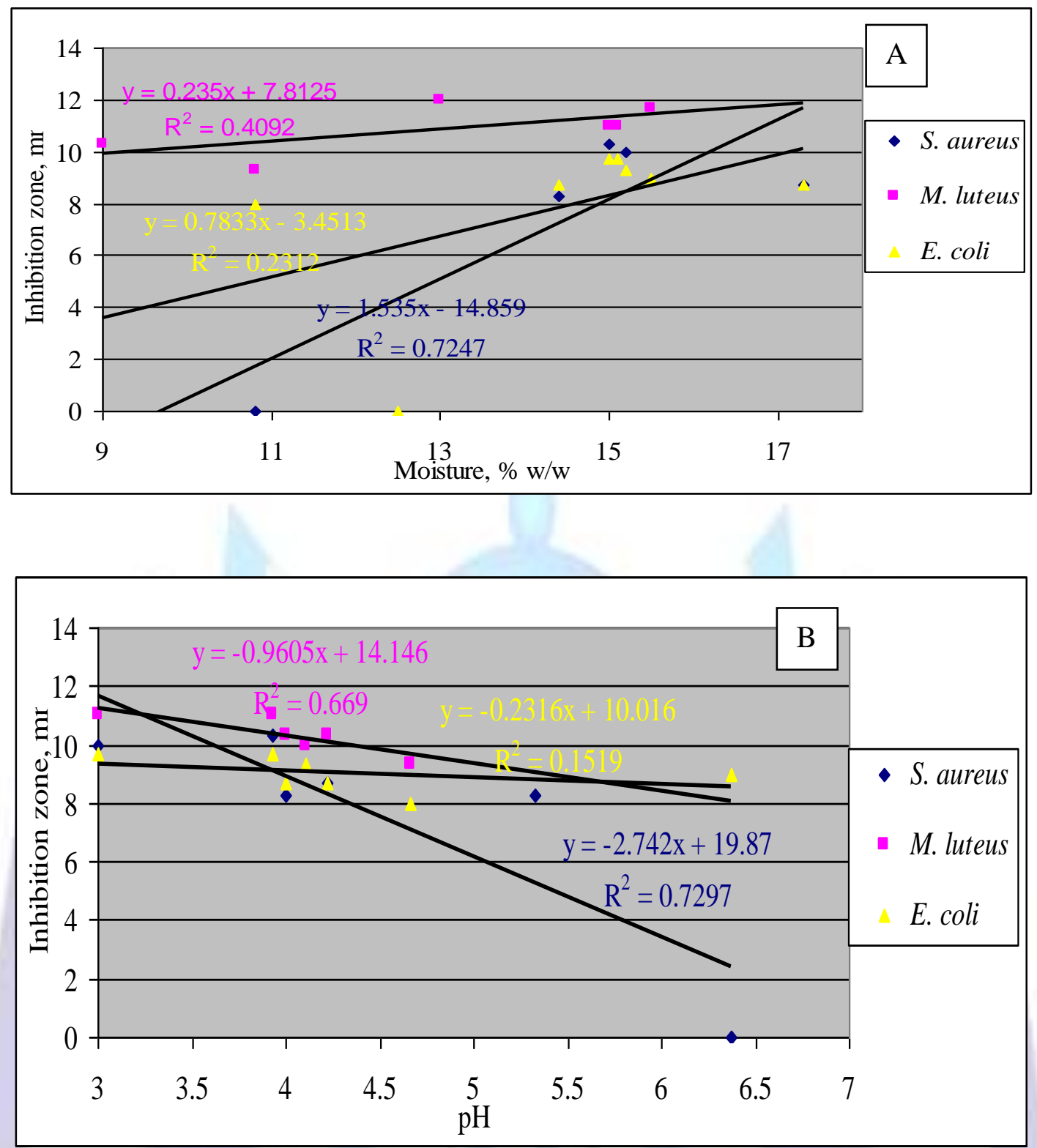

Fig.2 Plot of moisture content (\%w/w) (A) and $\mathrm{pH}(\mathrm{B})$ of honey samples vs. inhibition zone (mm) of S. aureus, M. luteus and E. coli.

$\pm 1.4,17.1 \pm 1.5$ and $31.0 \pm 1.2 \mathrm{~mm}$, respectively in agreement with the data reported earlier [5, 17]. Dark colored samples showed high antibacterial capacity in agreement with the data reported by Beretta et al. 2005 [5]and Estevinho et al. 2008 [23]. The differences in sample concentrations were significant in the antibacterial effect at $p=0.05$. New strategies to treat wounds infected with $S$. aureus and the use of honey as a convenient and low cost option is of great importance. High antioxidant and antibacterial activity were detected in darkest honey. Phenols, flavonoids, ascorbic acid, betacarotene and sugars content in the dark honey samples account for the trend observed. 
Table 2 Antimicrobial activities of diluted (10-100\%) honey samples vs. S. aureus ${ }^{a}$

\begin{tabular}{|c|c|c|c|c|c|c|}
\hline \multirow[t]{3}{*}{ Sample No. } & \multicolumn{6}{|c|}{ Inhibition zone diameter $(\mathrm{mm})^{\mathrm{a}}$} \\
\hline & \multicolumn{6}{|c|}{ Concentrations $(w / w)$ of diluted honey } \\
\hline & $10 \%$ & $20 \%$ & $40 \%$ & $60 \%$ & $80 \%$ & $100 \%$ \\
\hline 1 & $0^{\mathrm{a}}$ & $22^{\mathrm{b}} \pm 1.73$ & $28^{\mathrm{C}} \pm 1$ & $32^{\mathrm{de}} \pm 2$ & $32^{\mathrm{e}} \pm 1$ & $37^{\dagger} \pm 2$ \\
\hline 2 & $0^{\mathrm{a}}$ & $0^{\mathrm{a}}$ & $8^{b} \pm 1$ & $12^{\mathrm{C}} \pm 1$ & $17^{\mathrm{d}} \pm 1$ & $21^{e} \pm 1$ \\
\hline 3 & $0^{\mathrm{a}}$ & $0^{\mathrm{a}}$ & $13^{\mathrm{bc}} \pm 1$ & $14^{\mathrm{C}} \pm 1$ & $19^{\mathrm{de}} \pm 1$ & $20^{\mathrm{e}} \pm 1$ \\
\hline 4 & $0^{\mathrm{a}}$ & $0^{a}$ & $12^{b} \pm 2$ & $14^{\mathrm{c}} \pm 1$ & $17^{d} \pm 2$ & $19^{\mathrm{e}} \pm 1$ \\
\hline 5 & $0^{\mathrm{a}}$ & $24^{\mathrm{b}} \pm 1$ & $26^{\mathrm{C}} \pm 1$ & $32^{d} \pm 2$ & $36^{\mathrm{e}} \pm 1$ & $34^{\dagger} \pm 1$ \\
\hline 6 & $0^{\mathrm{a}}$ & $21^{\mathrm{b}} \pm 1$ & $28^{\mathrm{C}} \pm 1$ & $30^{\mathrm{d}} \pm 1$ & $32^{\mathrm{e}} \pm 2$ & $38^{\dagger} \pm 1$ \\
\hline 7 & $0^{\mathrm{a}}$ & $0^{\mathrm{a}}$ & $28^{b c} \pm 1$ & $28^{c} \pm 2.65$ & $32^{\mathrm{de}} \pm 2$ & $32^{\mathrm{e}} \pm 3$ \\
\hline 8 & $0^{\mathrm{a}}$ & $12^{b} \pm 2$ & $24^{c} \pm 2$ & $30^{\text {det }} \pm 1$ & $30^{\mathrm{et}} \pm 1$ & $32^{\dagger} \pm 1$ \\
\hline 9 & $0^{a}$ & $28^{\mathrm{b}} \pm 1$ & $34^{\text {cde }} \pm 1$ & $36^{\mathrm{de}} \pm 1$ & $36^{e} \pm 1$ & $40^{\dagger} \pm 1$ \\
\hline 10 & $0^{a}$ & $26^{\mathrm{b}} \pm 1$ & $30^{\mathrm{ce}} \pm 1$ & $32^{d} \pm 1.73$ & $30^{e} \pm 1$ & $34^{\dagger} \pm 2$ \\
\hline 11 & $0^{\mathrm{a}}$ & $28^{\text {bcde }} \pm 1$ & $28^{\text {cde }} \pm 1$ & $28^{\mathrm{de}} \pm 1$ & $30^{\mathrm{e}} \pm 1.73$ & $34^{\dagger} \pm 1$ \\
\hline 12 & $0^{\mathrm{a}}$ & $24^{b} \pm 3$ & $34^{\mathrm{cd}} \pm 1$ & $32^{\mathrm{de}} \pm 2$ & $30^{\mathrm{et}} \pm 1$ & $28^{\dagger} \pm 3$ \\
\hline 13 & $0^{a}$ & $24^{\mathrm{b}} \pm 1$ & $32^{\text {cdet }} \pm 1$ & $32^{\text {det }} \pm 1$ & $30^{\text {et }} \pm 1$ & $30^{\dagger} \pm 1$ \\
\hline 14 & $0^{\mathrm{a}}$ & $20^{\mathrm{b}} \pm 1$ & $28^{\text {cdet }} \pm 1$ & $28^{\text {det }} \pm 0$ & $30^{\text {et }} \pm 2$ & $28^{\dagger} \pm 1$ \\
\hline 15 & $0^{a}$ & $18^{b} \pm 1$ & $32^{\mathrm{cd}} \pm 1$ & $32^{d} \pm 1$ & $38^{\text {et }} \pm 1$ & $38^{\dagger} \pm 1$ \\
\hline 16 & $0^{\mathrm{a}}$ & $28^{\mathrm{bct}} \pm 1$ & $30^{\text {cdt }} \pm 1$ & $32^{\mathrm{dt}} \pm 1.73$ & $36^{\mathrm{e}} \pm 2$ & $30^{\dagger} \pm 1$ \\
\hline 17 & $0^{a}$ & $26^{b} \pm 1$ & $32^{c d} \pm 1$ & $32^{d} \pm 3$ & $36^{\mathrm{e}} \pm 1$ & $40^{\dagger} \pm 1$ \\
\hline 18 & $0^{a}$ & $26^{\mathrm{b}} \pm 1$ & $30^{c} \pm 1.73$ & $36^{\mathrm{de}} \pm 1$ & $36^{e} \pm 1$ & $34^{\dagger} \pm 1$ \\
\hline 19 & $0^{a}$ & $22^{\mathrm{b}} \pm 1$ & $30^{\mathrm{cd}} \pm 2$ & $30^{d} \pm 1$ & $35^{\text {et }} \pm 2$ & $33^{\dagger} \pm 1$ \\
\hline 20 & $0^{\mathrm{a}}$ & $23^{b} \pm 1$ & $30^{\text {cde }} \pm 3$ & $32^{\mathrm{de}} \pm 1$ & $32^{\mathrm{e}} \pm 1$ & $36^{\dagger} \pm 2$ \\
\hline
\end{tabular}

${ }^{a}$ Average $(n=3) \pm$ standard deviation. The mean difference is significant at the 0.05 level.

(0) means no antibacterial activity or inhibition.

Different superscripts denote significant differences at $p<0.05$.

\subsection{Influence of physicochemical properties of raw honey on the Lovibond comparator scale}

The effect of physicochemical parameters (total acidity, ash and moisture content, $\mathrm{pH}$ and color) of honey on $P$ fund color scale, $(\mathrm{mm})$ was studied. The results are summarized in Table 3 . Based on $P$ fund color scale, the color of samples ranged from water white $(P=0.0-1.3)$ (sample numbers 10,14 and 18), extra light Amber $(P=38.14-46.57)$, light Amber $(P=60.39-75.54)$, Amber $(P=86.72-110.08)$, dark $(P=142.39-348.44)$ and very dark shade $(P=541.84)$. The results reflect the pigment content e.g. carotenoids and flavanoids. Dark honeys contain more minerals than the lighter ones [21]. Good correlation between $P$ fund color scale and inhibition zone $\left(R^{2}=0.65-0.68\right)$ of the organisms was noticed. 
Table $3 P$ fund scale of colored honey samples

\begin{tabular}{|c|c|c|c|c|c|}
\hline $\begin{array}{c}\text { Honey } \\
\text { sample } \\
\text { no. }\end{array}$ & $P$ fund scale & $\begin{array}{c}P \text { fund } \\
\text { Grader color }\end{array}$ & $\begin{array}{l}\text { Honey } \\
\text { sample }\end{array}$ & $P$ fund scale & $\begin{array}{c}P \text { fund } \\
\text { Grader color }\end{array}$ \\
\hline 1 & 60.39 & Light Amber & 11 & 156.47 & Dark \\
\hline 2 & 46.57 & Extra Light Amber & 12 & 41.30 & Extra Light Amber \\
\hline 3 & 88.02 & Amber & 13 & 38.14 & Extra Light Amber \\
\hline 4 & 66.03 & Light Amber & 14 & 0.00 & Water White \\
\hline 5 & 142.39 & Dark & 15 & 348.44 & Dark \\
\hline 6 & 212.77 & Dark & 16 & 58.75 & Light Amber \\
\hline 7 & 549.84 & Very dark & 17 & 110.08 & Amber \\
\hline 8 & 74.76 & Light Amber & 18 & 1.30 & Water White \\
\hline 9 & 86.72 & Amber & 19 & 75.54 & Light Amber \\
\hline & 0.41 & Water White & 20 & 338.89 & Dark \\
\hline 10 & & & & & \\
\hline
\end{tabular}

\section{CONCLUSIONS}

Uni floral samples showed "non-peroxide" anti-QS and antimicrobial activity does not correlated linearly with the total and individual phenolic compounds. Colors of honey samples varied from water white to very dark shade. $\mathrm{pH}$, total acidity, moisture and ash content of the honey samples were comparable and / or equivalent to values reported for U.S. honey. Work is continuing to study which honey constituents are responsible for "non-peroxide" anti-QS activity.

\section{REFERENCES}

[1] Balsa, M., Canddiracci, M., Accorsi, A., Piacentini, M.P., Albertini, M.C., Piatti, E. 2006 Raw Millefiori Honey is Packed Full of Antioxidants. Food Chemistry 97, 217-222.

[2] Lambert, O., Piroux, M., Puyo, S., Thorin, C., Larhantec, M., Delbac, F., Pouliquen, F. 2012 Bees, Honey and Pollen as Sentinels for Lead Environmental Contamination. Environmental Pollution 170, 254-259.

[3] Aljadi, A. M., \& Yusoff, K. M. 2003. Isolation and Identification of Phenolic Acids in Malaysian Honey with Antibacterial Properties. Turkish Journal of Medical Science, 33, 229 -236.

[4] Weston, R. J. 2000. The Contribution of Catalase and Other Natural Products to the Antibacterial Activity of Honey: Food Chemistry, 71, 235-243.

[5] Basualdo, C., Sgroy, V., Finola, M.S., Marioli, J.M. 2007. Comparison of the 
Antibacterial Activity of Honey from Different Provenance Against Bacteria Usually Isolated from Skin Wounds. Veterinary Microbiology 124 (3-4), 375-381.

[6] Kucuk, M., Kolayl, S., Karaog`lu, S.I., Ulusoy, E., Baltac, C., Candan, F.2007 Biological Activities and Chemical Composition of Three Honeys of Different Types from Anatolia. Food Chemistry 100, 526 -534.

[7] Truchado,P., Lopez-Galvez,F., Gil,M.I. Tomas-Barberan, F.A., Allende, A. 2009 Quorum Sensing Inhibitory and Antimicrobial Activities of Honeys and the Relationship with Individual Phenolics. Food Chemistry, 115, 1337-1344.

[8] Ganash,M.A., Mujallid, M.I., Al-Robai, A.A., Bazzaz, A.A. 2014 Cytoprotectivity of the Natural Honey Against the Toxic Effects of Doxorubicin in Mice. Advances in Bioscience and Biotechnology 5, 252-260.

[9] Popova, M. P., Bankova, V. S., Bogdanov, S., Tsevetkova, I., Naydenski, C.,

Marcazzan, G. L. 2007 Chemical Characteristics of Poplar Type Propolis of Different Geographic Origin. Apidologie38, 306-311.

[10] Al Lawati,H.A.J., Al Haddabi, B., FakhrEldin O. Suliman, F.O. 2014. A Novel Microfluidic Device for Estimating the Total Phenolic/Antioxidant Level in Honey Samples Using a Formaldehyde/Potassium Permanganate Chemiluminescence System. Anal. Methods. 6, 7243-7249.

[11] Beretta, G., Granata, P., Ferrero, M., Orioli, M., \& Facino, R.M. 2005 Standardization of Antioxidant Properties of Honey by a Combination of Spectrophotometric/Fluorimetric Assays and Chemometrics. Analytical Chimica Acta, 533, 185-191.

[12] Gomes, S., Dias, L.G., Moreira, L.L., Rodrigues, P. Estevinho, L. 2010 Physicochemical, Microbiological and Antimicrobial Properties of Commercial Honeys from Portugal. Food and Chemical Toxicology 48, 544-548.

[13] Al-Hindi, R.K., Bin-Masalam, M.S., El-Shahawi, M.S. 2011. Antioxidant and Antibacterial Characteristics of Phenolic Extracts of Locally Produced Honey in Saudi Arabia. International Journal of Food Sciences and Nutrition, 62(5), 513-517.

[14] Patton, T., Barrett, J., Brennan, J., Moran, N. 2006 Use of a Spectrophotometric Bioassay for Determination of Microbial Sensitivity to Manuka Honey. Journal of Microbiological Methods, 64, 84- 95.

[15] Bertoncelj, J, Doberšek, U., Jamnik, M. and Golob, T. 2007 Evaluation of the

Phenolic Content, Antioxidant Activity and Color of Slovenian Honey. Food Chemistry 105 (2) 822-828.

[16] Finola,M.S., Lasagno, M.C. and Marioli, J.M. 2007 Microbiological and Chemical Characterization of Honeys from Central Argentina. Food Chemistry 100 (4), 1649-1653.

[17] Ferreira, I.C.F.R., Aires, E., Berreira, J.C.M., Estivenho, L.M. 2009 Antioxidant

Activity of Portuguese Honey Samples: Different Contributions of the Entire Honey and Phenolic Extract. Food Chemistry 114 (4), 1438-1443.

[18] Anklam, E. (1998). A Review of the Analytical Methods to Determine the Geographical and Botanical Origin of Honey. Food Chemistry 63 (4), 549-562.

[19] Varshneya, C, Kant, V, Metha, M. 2012 Total Phenolic Contents and Free Radical

Scavenging Activities of Different Extracts of Seabuckthorn (Hippophae Rhamnoides)

Pomace Without Seeds. International Journal of Food Sciences and Nutrition, 63(2),

153-159.

[20] Al-Doghairi, M.A., Al-Rehiayani, S., Ibrahim, G.H., Osman, K.A. 2007. Physicochemical and Antimicrobial Properties of Natural Honeys Aroduced in Al.Qassim Region. Saudi Arabia. Metabolism of Environment of Arid Land Agriculture. Science. 18 (2), 3-18.

[21] Anupama, D., Bhat, K.K. and Sapna, V.K. (2003). Sensory and Physicochemical Properties of Commercial Samples of Honey. Food Research International. 36 (2), 183-191.

[22] Lusby, P.E., Coombes, A.L. and Wilkinson, J.M. 2005 Bactericidal Activity of Different Honeys Against Pathogenic Bacteria. Archives of Medical Research 36 (5), 464- 467

[23] Estevinho, L., Pereira, A.P., Moreira, L., Dias, L.G., Pereira, E.2008 Antioxidant and Antimicrobial Affects of Phenolic Compounds Extracts of Northeast Portugal Honey. Food and Chemical Toxicology 46, $3774-3779$. 